\title{
Iranian Steel Industry: Domination of Dispersed Direct Reduction Plants in an Inefficient Value Chain and a Droughty Environment
}

\section{Sepehr Ghazinoory}

Tarbiat Modares University Faculty of Management and Economics

Mehdi Fatemi ( $\nabla$ mehdifatemy@modares.ac.ir)

Tarbiat Modares University https://orcid.org/0000-0002-4095-5675

Abolfazl Adab

National Research Institute for Science Policy

\section{Research Article}

Keywords: Value Chain Analysis, Material Flow Analysis, Steel Industry, Iran

Posted Date: December 8th, 2021

DOI: https://doi.org/10.21203/rs.3.rs-1132632/v1

License: (c) (i) This work is licensed under a Creative Commons Attribution 4.0 International License. Read Full License 


\section{Abstract}

Iran has a great advantage in the development of the steel industry due to its access to mineral resources and energy, extensive consumer market, and low-cost labor. In this article, the Iranian steel value chain in 2014-2016 is studied using the value chain analysis and material flow analysis. Accordingly, based on the statistics related to the input and output of each echelon in the chain, the material flow is analyzed throughout the value chain. Then the total added value from the chain, the share of different stages, and the various costs in each echelon are calculated. According to the research findings, weakness in the development of transportation infrastructure and poor geographical distribution of value chain units has led to the deviation of production from nominal capacity and frequent imports/exports throughout the chain. On the other hand, the upstream industries have a permanent advantage that deeply roots in easy access to the minerals and lower costs in transportation and energy. Finally, the pricing of intermediate products based on the ratio of steel ingot prices is criticized, while wage conversion and commodity purification contracts are proposed as possible solutions for the reduction of overhead costs.

\section{Introduction}

As the steel industry plays an important role in economic development, its production and consumption are considered as one of the main indicators of the development of modern countries and societies (Azadeh et al, 2010; Jozi \& Majd, 2014). According to its capital-intensive and high-tech nature, the steel industry not only had a direct impact on the industrialization of Western countries in the past but also has played a critical role in the development of East Asian countries in recent decades, whereas the steel industry lead has shifted from the U.S. to Japan and later to South Korea (Kumar \& Chadha, 2009; Lee \& Ki, 2017).

Due to the geopolitical position and the access to natural resources of Iran, there has been special attention to the steel industry in this country since the 1930s (Analoui et al., 2000). Iran has a comparative advantage over some industrialized countries in the industry according to its rich iron ore mines, energy resources, growing consumer market, and young labor force (Shakouri, 2017). Also, such countries (including the EU members) supply most of the iron ore and energy needed to produce steel through imports and therefore are more vulnerable to the fluctuation of the global price of iron ore and coal comparing to Iran (Dudin, 2017). Accordingly, in the last five years, Iran has been the first producer of iron ore and the second-largest producer of steel (after Turkey) in the MENA region (Reichl et al., 2016; Hastorun et al., 2016). The steel industry in Iran is governed by the government as $96 \%$ and $70 \%$ of crude and final steel is produced by state-owned companies, respectively (Ansari \& Seifi, 2012) and the largest steel producers in the country are the state-owned companies (Mobarakeh Steel, Khuzestan Steel and Isfahan Steel with a market share of $47 \%, 23 \%$, and $20 \%$ respectively) (Arabzad et al., 2017; Nabatian et al., 2015).

In the last four decades, over 150 million tons of crude steel have been produced in Iran and 200 million tons of steel have been used in the construction of residential buildings and factories, the development of communication routes, car production, energy, fluid transmission, etc. (Rahdari et al., 2007; Mehmanpazir et al., 2019). According to the strategic vision of Iran, its steel production should reach more than 50 million tons per year in 2025 (Shahabi et al., 2014; Mahjouri et al., 2017; Kordzadeh et al., 2018; Mabashi, 2018), which is in line with the projected growth in global steel demand (from 1.410 million tons in 2010 to 2.200 million tons in 2050) (Xiong \& Helo 2008; Hasanbeigi et al., 2014). However, the activity of half of Iran's downstream steel industries with a capacity less than their nominal capacity has posed a serious challenge to this industry in achieving these goals (Hastourn et al., 2016), and therefore the understanding and analysis of the steel value chain are vital to the optimization of the development pattern of the industry.

Value chain analysis is a useful tool in policymaking as it demonstrates a continuous view of the entire chain, depicts the activities of the value chain, and separates the total revenue of each firm in the chain. There are numerous justifications for the analysis and understanding the value chain, including the need for systematic competitiveness due to the dispersion of production in the global system, the importance of production productivity on the path to success in the global market, and finally the necessity to understand the dynamics of the critical factors in the value chain (Kaplinsky, 2000; Kaplinsky \& Morris, 2000). In addition to the understanding of the current situation in the distribution of income, value chain analysis can identify the causal factors and further design a set of transformational measures according to the following reasons (Subramanian, 2007, 2; Adab et al., 2019):

Page $2 / 21$ 
- The holistic view of the value chain on the various rent-creator components, shows which activities in the value chain can generate high revenue.

- Relying on the value chain, it is possible to identify overly competitive activities and bottleneck activities, and thus balance the chain in the long run.

- Value chain attention to power relations and institutions explains which and whose behavior needs to change for the emergence of new outputs or different distribution of the outputs.

- Value chain analysis does not end at the level of the firm or group of firms and also pays attention to national innovation systems.

The role of value chain imbalances is evident in the problems in the supply of raw materials in Iranian steel mills. Also as a result of the lack of sufficient information and delay in the feedback mechanisms for the decision-making of investors and managers, the problem of raw material supply is displayed in different nodes throughout the years. For example, at present, based on the production capacity of Iran's factories in the top three links of the value chain, there is a shortage of 1 and 7.3 million tons per year in the production of sponge iron and iron pellets, respectively, and a surplus of about 2 million tons per year in the production of concentrate. Also, the actual production in each of these nodes is very different from the nominal capacity, and the imbalance in the various nodes of the chain has forced the country to import intermediate goods and sometimes export upstream goods of the industry, which yields the least added value. On the other hand, due to the geographical distribution of chain nodes in Iran and the unfavorable situation of the quantity and productivity of the road transport fleet, the exchange of raw materials and intermediate goods leads to bottlenecks in chain linkages. Also, water consumption in the steel industry is one of the other challenges facing this production chain due to the placement of various iron ore extraction and processing units in water-scarce areas; which makes it impossible to achieve the target of 55 million tons given the ongoing water crisis in Iran and the need for 98 million square meters of water to achieve the target. (Shakouri, 2017). Accordingly, the need to upgrade the value chain of Iran's steel industry in interaction with the global value chain becomes more apparent due to the need to increase the country's foreign exchange earnings and export planning of 15 million tons of steel products in 2025. Therefore this article seeks to evaluate the status of different nodes of the value chain of the Iranian steel industry in 2014-2016 (due to the international sanctions of the country in the next years) using the value chain and the material flow analysis.

\section{Literature Review}

\subsection{Value Chain}

The origins of the value chain notion go back to earlier concepts such as filler approach and commodity chain in the 1960s and 1970s, although some scholars believe that Davis and Goldberg used the concept in agricultural research back in 1957 (Faße et al., 2009). Porter explains the concept of the value chain in his book "Competitive Advantage: Creating and Maintaining Superior Performance" (1985) (Dekker, 2003), whereas the value chain is a framework for identifying the key activities of the organization through which the organization can achieve competitive advantage. (Hartwich \& Kormawa, 2009). Value chain represents a range of necessary activities for the transfer of a product or service from conceptual definition and initial idea to different phases of production (including the procurement of raw materials needed for production and a combination of physical transformations) and then further to the delivery to the final customer and finally post-consumption recycling. However in the real world, the value chain is usually more complex than the simple model mentioned above, and the simplest extension of the model is obtained by adding different products along the value chain. Also, the producers of the intermediate goods may present their products in different value chains, which increases the complexity of value chain analysis (Kaplinsky \& Morris, 2003). Accordingly, other researchers have further developed the value chain approach by shifting their focus from one firm to a group of partner firms in creating related value. This definition of the value chain includes a range of core activities (production, sales, and distribution) and support (planning, research and development, and human resources) for the transferring of a product or service from conceptual definition and initial idea to different phases of production toward the delivery to the final customer (Hellin \& Meijer, 2006; Fearne et al., 2012). By promoting this approach in the mid-2000s among 
researchers (Savino et al., 2015), the concept of value chain spread in other research areas in the form of concepts such as knowledge value chain (Lee \& Yang, 2000), innovation value chain (Hansen \& Birkinshaw, 2007; Roper et al., 2008) and the customer value chain (Donaldson et al., 2004; Pil \& Holweg, 2006).

\subsection{Steel Value Chain}

Steel is produced mainly through 1) blast furnace converter and scrap smelting technology or 2)direct reduction technology and electric arc furnace, although the production via recycling of steel scrap can be considered as an alternative as well (Johansson \& Soderstrum, 2011; Mahjouri et al, 2017) (Fig. 1). While in 2018, 70.7\% of the world's crude steel was produced by blast furnace method, $28.9 \%$ by direct reduction method, and $0.5 \%$ by other methods, Iran produces $90.8 \%$ out of total 24.5 million tons production via direct reduction due to its access to natural gas instead of coal (World Steel Association, 2019). The only company active in the production of crude steel by blast furnace method is Isfahan Steel Company (Ansari \& Seifi, 2012; Arabzad et al., 2017) and only two projects with this technology will be inaugurated soon.

\subsection{Previous Studies of Steel Value Chain}

The study of the value chain of the steel industry in different countries can be classified into two main clusters. The first group of studies used the material flow analysis to analyze the flow of raw materials and steel scrap, optimize energy consumption or calculate the amount of carbon production along the chain. For example, Panasiyk et al. (2016) used a material flow analysis methodology to examine the European steel value chain from 1954 to 2013. Michaelis and Jackson (2000a; 2000b) analyzed the material flow and energy flow of the UK steel sector which is reflected in two articles (studying the periods of 1954-1994 and 1994-2019). Gauffin et al. (2016) mapped the steel industry value chain to model the annual consumption and supply of scrap iron, but used only steel production data and ignored the flow of other materials in the steel industry value chain. Andersen and Hyman (2000) also studied the flow of materials and energy in the US steel industry which also uses blast furnace technology and recycling of steel waste with electric arc furnace technology. Yellishetty et al. (2010) analyzed the flow of materials in the iron and steel industry in the period 1950 to 2005, and then further predicted the flow of materials in the production of iron and steel worldwide. According to the results of this study, the main producing countries of iron ore are not among the pioneer manufacturers of steel and vice versa; Brazil's iron ore production in 2005, for example, was 10 times of its steel production, while Japan was the world's second-largest producer of steel without much domestic iron ore production.

The second group of studies has calculated the added value of the whole chain and its links. Since a significant part of production costs in each chain is allocated to energy, some studies categorized under this group also aimed to optimize energy consumption. Johansson and Söderström (2011) examined the value chains of two different Swedish plants with scrap metal and blast furnace technology to identify the opportunities for higher productivity in fossil energy consumption and lower carbon dioxide emissions. Ecorys SCS Group (2008) analyzed the value chain of the European steel industry and calculated the added value of the whole chain, regardless of the added value of each linkage in the chain. In the overall value chain of the steel industry according to McKinsey (2013), the profitability has been challenged recently and profit margins have moved toward the upstream of the value chain and even mining. For example, comparing the steel value chain in Brazil with Western European countries, based on earnings before interest, taxes, and depreciation in the period 2008 to 2012, the profit margin of the entire chain in Brazil decreased from $49-34 \%$, while rose from $27-5 \%$ Western European countries, largely due to Brazil's advantage in accessing mines and the development of upstream value plants. Dahlström et al. (2004) and Dahlström and Ekins $(2006$; 2007) analyzed the material flow and its economic dimensions in the UK steel and aluminum industry but neglected direct reduction technology as it's not popular in the context of the study.

Therefore the necessity of the present study can be emphasized from four aspects. The first aspect is the growing importance of the steel industry in the Iranian economy, based on which the economic analysis of the value chain of the steel industry is necessary due to the low performance and productivity of the value chain of this industry in this country. Secondly, the development pattern of the steel industry in Iran has led to various environmental crises, especially the water crisis in some provinces of the country, and this issue has even challenged the stability of the industry as well. From another perspective, the special emphasis on balanced development in the supply of raw materials and intermediate goods steel industry in the upstream policies of Iran is another dimension of the present research that has not been considered in previous studies as 
most of these studies aim to increase energy efficiency (Ansari \& Seifi, 2012; Hasanbeigi et al., 2013; He et al., 2018), reduce carbon dioxide production (Sitonen et al., 2010; Pal et al., 2016), develop green technologies (Shekari et al., 2011; Dudin, 2017) or analyze the steel supply, demand, and price (Rahdari et al., 2007; Nezhad \& Anvari, 2008; Mehmanpazir et al., 2019). The last aspect of research necessity is the relative reliance of Iran's steel industry on arc technology comparing to the rest of the world as most studies have analyzed the chain based on blast furnace technology (such as Dahlström \& Ekins (2006)). Thus the present study analyzes the value chain in the steel industry based on electric arc technology for the first time.

\section{Research Methodology}

As material flow analysis and economic value chain analysis have been used simultaneously in this article, each is briefly introduced to further explain the research method.

\subsection{Material Flow Analysis}

According to Brunner and Rechberger, material flow analysis systematically examines the flow and storage of materials in various industrial sectors or ecosystems (Brunner \& Rechberger, 2004) and leads to a better understanding of industry metabolism (Michaelis \& Jackson, 2000a; 2000b) and the complex interactions between economic activity and the environment (Fischer-Kowalski \& Hüttler, 1998). This popular analysis in resource policy, energy planning, environmental studies, and waste management (Yellishetty et al., 2010) is not solely sufficient to evaluate or support industrial activities but still provides a common ground for further system analysis (Fischer-Kowalski \& Hüttler, 1998). As material flow analysis is based on system thinking and the mass conservation principle, it starts with the definition of the system as the starting point. Then it tracks the amount of material passing through the system using the concept of mass conservation (GTZ Eschborn, 2007), which leads to the development of a visual scheme of the flow throughout the system.

\subsection{Value Chain Analysis}

Value chain analysis is developed to apply the concept of the value chain in policymaking. There are various methodologies for value chain analysis that have much in common. For example, Kaplinsky suggests the selection of the entry point into value chain analysis, value chain mapping, quantification and economic analysis of value chain, production productivity benchmark, and examination of the role of governance in the value chain (Kaplinsky, 2000; Kaplinsky \& Morris, 2000), with qualitative drawing and illustration of the chain as the most critical step (Springer- Heinze, 2007).

Among the various steps of value chain analysis, the economic analysis includes the evaluation of the total added value from the chain, the share of different stages, the costs of each stage, and the performance of operators (utilization of the capacity, profitability, and effectiveness). In contrast to the firm-level evaluations, economic analysis studies the value chain from the perspective of the economic society and considers factors such as shadow prices and opportunity costs in a short and specific period (often one year) (Faße et al., 2009). This value chain analysis method has been used in various contexts including steel and aluminum industries in the UK (Dahlström \& Ekins, 2006; 2007), jatropha-based biodiesel in India (Shinoj et al., 2010), Marcellus Shale Well Site in Southwestern Pennsylvania (Hefley \& Cider, 2011), taxi fleet with a battery-swapping mode in a pilot city (Ning et al., 2012), Fresh chestnuts industry worldwide (Savino et al., 2015) and small-scale fisheries between Fiji and Kiribati (Purcell et al., 2017).

\subsection{The framework of Value Chain Analysis for Iran's steel industry}

The first step in material flow analysis is to precisely define the system and determine its boundaries. In this article, the steel industry includes the industries, factories, and sectors active in the process of converting mineral iron ore into steel sections and profiles. In other words, the system starts from iron ore mines and ends in rolling and profiling units. Supply units of other materials and equipment of the main value chain, such as factories producing ferroalloys, lime, refractories, parts, accessories, etc., which are somehow related to the main value chain, are defined outside the system. This is because these units often operate in more than one industry (for example, refractory plants are also in the supply chain of the cement industry and other smelting industries). This step is equivalent to drawing a value chain in the value chain analysis methodology. 
Annual production and sales in each link of the value chain are the key system data used in material flow analysis. In this study, inventory in each fiscal year is assumed to be negligible, although this hypothesis is not very accurate in some cases. Also, the existing coefficients between different links in the chain are selected based on the monitoring studies of the comprehensive plan of the Iran steel industry[1] and are defined based on the amount of raw material used in each echelon. In material flow analysis, the output of one echelon is either consumed in other echelons or stored/exported as surplus goods. On the other hand, the input of an echelon may is provided either through the previous echelon or from imports. Therefore, the total output of an echelon $\left(E_{T}\right)$ is defined according to equation 1:

(1) $E_{T}=\varepsilon_{n}+\varepsilon_{e} \equiv m\left(\varepsilon_{n-1}+I\right)+O$

In this equation $\epsilon_{n}$ and $\epsilon_{n-1}$ are the amounts of production of the existing and the previous echelon, that are directly consumed by the chain; $\epsilon_{e}$ is the amount of production that leaves through exports; $m$ is the conversion factor of the material from the previous echelon to The new one (Table 1 ); $I$ is the supply of echelon material through imports and finally, $O$ is the entry of raw materials into the echelon from other sources. It is worth mentioning that in some cases, there is a slight difference in the values of input and output of each echelon, which is due to the error of the ring coefficients, the use of stored raw materials, or the supply of raw materials from other sources. However, the error is insignificant as the recorded statistics are relatively consistent in the boundaries of the system.

Table 1

conversion factor of the materials in the Iranian steel value chain

\begin{tabular}{|c|c|c|c|c|c|c|}
\hline \multicolumn{7}{|c|}{ A- Direct Reduction Method } \\
\hline & Iron Ore & Concentrate & & Iron Ore Pellet & Sponge Iron & Crude steel \\
\hline Total & 3 & 1.82 & & 1.69 & 1.1 & 1 \\
\hline Step 1 & 1.65 & 1 & & & & \\
\hline Step 2 & & 1.07 & & 1 & & \\
\hline Step 3 & & & & 1.54 & 1 & \\
\hline Step 4 & & & & & 1.1 & 1 \\
\hline \multicolumn{7}{|c|}{ B- Blast Furnace Method } \\
\hline & \multicolumn{2}{|c|}{ Granulated Iron Ore } & Lump & \multicolumn{2}{|c|}{ Cast Iron } & Crude steel \\
\hline Total & \multicolumn{2}{|l|}{2} & 1.33 & \multicolumn{2}{|l|}{1} & 1 \\
\hline Step 1 & \multicolumn{2}{|l|}{1.5} & 1 & & & \\
\hline Step 2 & & & 1.33 & \multicolumn{2}{|l|}{1} & \\
\hline Step 3 & & & & \multicolumn{2}{|l|}{1} & \\
\hline
\end{tabular}

As previously mentioned, the value chain of crude steel production is analyzed based on the financial statements of companies during the period of 2014-2016. Due to the difficulty of accessing the financial information of all active companies, the necessary information is extracted based on the annual financial statements of 2 active companies. Also according to the public nature of the development of the steel industry chain in Iran, the differences in the productivity of various factories are negligible. Furthermore, the value-added calculations for selected companies in each link of the chain are generalized to the whole link given the relatively uniform behavior of the factories in a link chain which is approved by the experts. The cost of production or cost of $P_{t}$ is calculated according to equation 2, which includes all costs related to direct materials $\left(P_{i}\right)$, direct labor, and overhead costs $\left(C_{i}\right)$. 
(2) $P_{t}=\sum P_{i}+\sum C_{i}$

The most important point about the calculation of the overhead costs in production is the consideration of the cost of mining royalties or property rights, which is determined in the budget law each year. In the calculation of the overhead costs, all costs related to administrative, general, sales, operating, non-operating, and income tax are included. The net profit or revenue from the final sale is calculated by the deduction of final and overhead costs from the total sale (Equation 3 ).

(3) $A_{t}=S_{t}-P_{t}$

Financial costs, which are paid to provide the cash flow, are not included in the calculation of overhead costs and other items. Also, operating and non-operating revenues are not included in the profit calculation, because it is related to the profit of each company and not the profit of the whole value chain.

[1] This report is published annually in cooperation with the National Iranian Steel Company by National Iranian Steel Co. and Iranian Mines \& Mining Industries Development \& Renovation (IMIDRO). http://en.niscoir.com/portal/home

\section{Findings}

The material flow analysis of the steel industry chain was performed in two steps; in the first step, starting from the last link of the chain (the requirement of 39.2 tons of steel in the domestic market) and moving backward, the amount of production of each chain was calculated. In this method, the amount of supply (production by the blast furnace method, scrap, import, etc.) and consumption (surplus and export) based on alternative routes are also considered based on the statistics to provide a clear picture of the steel industry value chain (Table 2 for 2016). 
Table 2

Material flow calculation of Iranian steel industry in 2016 based on production in the last echelon of the chain (million tons)

\begin{tabular}{|c|c|c|c|c|c|}
\hline & $\begin{array}{l}\text { Production in } \\
\text { the following } \\
\text { echelon }\end{array}$ & $\begin{array}{l}\text { Conversion } \\
\text { factor in } \\
\text { the } \\
\text { following } \\
\text { echelon }\end{array}$ & $\begin{array}{l}\text { Production } \\
\text { required for the } \\
\text { supply of the } \\
\text { following chain }\end{array}$ & $\begin{array}{l}\text { Supply from /consumption } \\
\text { in alternative routes }\end{array}$ & $\begin{array}{l}\text { Required Capacity to } \\
\text { supply the following } \\
\text { echelon }\end{array}$ \\
\hline $\begin{array}{l}\text { Calculation } \\
\text { formula }\end{array}$ & $\begin{array}{l}\text { Extracted from } \\
\text { the last column } \\
\text { of the previous } \\
\text { row (exogenous } \\
\text { in the first row) }\end{array}$ & $\begin{array}{l}\text { Extracted } \\
\text { from Table } \\
1\end{array}$ & $\begin{array}{l}\text { Production in } \\
\text { the following } \\
\text { echelon* } \\
\text { conversion } \\
\text { factor in the } \\
\text { following } \\
\text { echelon }\end{array}$ & $\begin{array}{l}\text { Extracted from statistical } \\
\text { data on the amount of } \\
\text { production by the blast } \\
\text { furnace method, import, } \\
\text { scrap (+), export and } \\
\text { surplus (-) }\end{array}$ & $\begin{array}{l}\text { Production required } \\
\text { for the supply of the } \\
\text { following chain - } \\
\text { Supply from } \\
\text { /consumption in } \\
\text { alternative routes }\end{array}$ \\
\hline $\begin{array}{l}\text { Domestic } \\
\text { market }\end{array}$ & 39.2 & 1 & 39.2 & 9.6 & 29.8 \\
\hline $\begin{array}{l}\text { Rolling and } \\
\text { shaping }\end{array}$ & 29.8 & 1 & 29.8 & $3.6+3.4=7$ & 22.8 \\
\hline $\begin{array}{l}\text { Direct } \\
\text { reduction }\end{array}$ & 22.8 & 1.1 & 25.1 & 0.6 & 24.5 \\
\hline $\begin{array}{l}\text { Iron ore } \\
\text { process } 1 \\
\text { (pellet } \\
\text { production) }\end{array}$ & 24.5 & 1.54 & 37.7 & 5.7 & 32 \\
\hline $\begin{array}{l}\text { Iron ore } \\
\text { process } 2 \\
\text { (concentrate } \\
\text { production) }\end{array}$ & 32 & 1.07 & 34.3 & -10.1 & 44.4 \\
\hline $\begin{array}{l}\text { Domestic } \\
\text { Mines }\end{array}$ & 44.4 & 1.65 & 73.3 & -7.2 & 75.5 \\
\hline
\end{tabular}

Accordingly, the material value chain of the steel industry of Iran in 2016 is presented in Figure 2.

Then, according to the capacity of the production chain (determined by sponge iron as the bottleneck), the actual production capacity of the chain (without using alternative methods of material supply) was calculated (Table 3 for 2016). 
Table 3

Actual material flow capacity of Iranian steel industry in 2016 based on the maximum production capacity of the bottleneck echelon (million tons)

\begin{tabular}{|c|c|c|c|}
\hline & Production in the following echelon & $\begin{array}{l}\text { Conversion factor } \\
\text { in the following } \\
\text { echelon }\end{array}$ & $\begin{array}{l}\text { Production required for the supply of } \\
\text { the following chain }\end{array}$ \\
\hline $\begin{array}{l}\text { Calculation } \\
\text { formula }\end{array}$ & $\begin{array}{l}\text { Extracted from the last column of the } \\
\text { previous row (exogenous in the first } \\
\text { row) }\end{array}$ & $\begin{array}{l}\text { Extracted from } \\
\text { Table } 1\end{array}$ & $\begin{array}{l}\text { Production in the following echelon } \\
{ }^{*} \text { conversion factor in the following } \\
\text { echelon }\end{array}$ \\
\hline Domestic market & 22.8 & 1 & 22.8 \\
\hline $\begin{array}{l}\text { Rolling and } \\
\text { shaping }\end{array}$ & 22.8 & 1.1 & 25.1 \\
\hline Direct reduction & 25.1 & 1.54 & 38.6 \\
\hline $\begin{array}{l}\text { Iron ore process } 1 \\
\text { (pellet production) }\end{array}$ & 38.6 & 1.07 & 41.5 \\
\hline $\begin{array}{l}\text { Iron ore process } 2 \\
\text { (concentrate } \\
\text { production) }\end{array}$ & 44.4 & 1.65 & 68.5 \\
\hline
\end{tabular}

Thus, the actual material chain in the steel industry (without the use of alternative methods of material supply) in 2016 is presented in Figure 3.

For the value chain analysis, the final and overhead costs and the operating profit and loss of various products in different factories are calculated. Accordingly, Table 4 presents the calculation procedure of the mentioned indexes for the products in Chadormalu Mining and Industrial Company[2] in 2016. 
Table 4

Final and overhead costs and Operating profit and loss of various products in Chadormalu Mining and Industry in 2016

\begin{tabular}{|c|c|c|c|c|c|c|c|c|}
\hline & $\begin{array}{l}\text { Calculation } \\
\text { formula }\end{array}$ & Concentrate & Granules & Pellet & Apatite & Total & $\begin{array}{l}\text { Financial I } \\
\text { (dollars) }\end{array}$ & \\
\hline $\begin{array}{l}\text { Production } \\
\text { (tons) }\end{array}$ & \multirow{3}{*}{$\begin{array}{l}\text { Extracted } \\
\text { from } \\
\text { financial } \\
\text { statements }\end{array}$} & 9054576 & 327325 & 3719849 & 66212 & 13167962 & $\begin{array}{l}\text { Total } \\
\text { sales }\end{array}$ & 598914286 \\
\hline $\begin{array}{l}\text { Sales } \\
\text { (tons) }\end{array}$ & & 6328533 & 283156 & 3730872 & 55195 & 10397756 & $\begin{array}{l}\text { Total } \\
\text { profits } \\
\text { and } \\
\text { losses }\end{array}$ & 198033029 \\
\hline $\begin{array}{l}\text { Total sales } \\
\text { amount of } \\
\text { each } \\
\text { product } \\
\text { (dollars) }\end{array}$ & & 299608714 & 7908114 & 288345629 & 3051829 & 598914286 & $\begin{array}{l}\text { Total } \\
\text { costs }\end{array}$ & 394402314 \\
\hline $\begin{array}{l}\text { Sale price } \\
\text { of product } \\
\text { per ton } \\
\text { (dollars) }\end{array}$ & $\begin{array}{l}\text { Total sales } \\
\text { amount of } \\
\text { each } \\
\text { product } \\
\text { (dollars)/ } \\
\text { sales } \\
\text { (tons) }\end{array}$ & 47.43 & 28.00 & 77.43 & 55.43 & - & $\begin{array}{l}\text { Overhead } \\
\text { Costs }\end{array}$ & 6478943 \\
\hline $\begin{array}{l}\text { Share of } \\
\text { each } \\
\text { product } \\
\text { from total } \\
\text { sales }\end{array}$ & $\begin{array}{l}\text { Sale price } \\
\text { of each ton } \\
\text { of the } \\
\text { product } \\
\text { (dollars)/ } \\
\text { sale price } \\
\text { of of each } \\
\text { ton of the } \\
\text { total } \\
\text { products } \\
\text { (dollars) }\end{array}$ & 0.500 & 0.013 & 0.481 & 0.005 & - & & \\
\hline $\begin{array}{l}\text { Operating } \\
\text { profit and } \\
\text { loss of } \\
\text { each } \\
\text { product } \\
\text { (dollars) }\end{array}$ & $\begin{array}{l}\text { Share of } \\
\text { each } \\
\text { product } \\
\text { from total } \\
\text { sales* } \\
\text { total } \\
\text { profits and } \\
\text { losses } \\
\text { (dollars) }\end{array}$ & 99066629 & 2614857 & 95342457 & 1009086 & & & \\
\hline $\begin{array}{l}\text { Operating } \\
\text { profit and } \\
\text { loss of } \\
\text { each } \\
\text { product } \\
\text { per ton } \\
\text { (dollars) }\end{array}$ & $\begin{array}{l}\text { Operating } \\
\text { profit and } \\
\text { loss of } \\
\text { each } \\
\text { product } \\
\text { (dollars)/ } \\
\text { sales } \\
\text { (tons) }\end{array}$ & 15.66 & 9.23 & 25.54 & 18.29 & & & \\
\hline $\begin{array}{l}\text { Final cost } \\
\text { of each } \\
\text { product } \\
\text { (dollars) }\end{array}$ & $\begin{array}{l}\text { Share of } \\
\text { each } \\
\text { product } \\
\text { from total } \\
\text { sales* } \\
\text { total costs } \\
\text { (dollars) }\end{array}$ & 197300971 & 5207714 & 189883914 & 2009714 & & & \\
\hline
\end{tabular}




\begin{tabular}{|c|c|c|c|c|c|c|c|}
\hline & $\begin{array}{l}\text { Calculation } \\
\text { formula }\end{array}$ & Concentrate & Granules & Pellet & Apatite & Total & $\begin{array}{l}\text { Financial Index } \\
\text { (dollars) }\end{array}$ \\
\hline $\begin{array}{l}\text { Final cost } \\
\text { of each } \\
\text { product } \\
\text { per ton } \\
\text { (dollars) }\end{array}$ & $\begin{array}{l}\text { Final cost } \\
\text { of each } \\
\text { product } \\
\text { (dollars/ } \\
\text { sales } \\
\text { (tons) }\end{array}$ & 31.17 & 18.40 & 50.89 & 36.40 & & \\
\hline $\begin{array}{l}\text { Overhead } \\
\text { costs of } \\
\text { each } \\
\text { product } \\
\text { (dollars) }\end{array}$ & $\begin{array}{l}\text { Share of } \\
\text { each } \\
\text { product } \\
\text { from total } \\
\text { sales * } \\
\text { overhead } \\
\text { costs } \\
\text { (dollars) }\end{array}$ & 3241114 & 85543 & 3119257 & 33000 & & \\
\hline $\begin{array}{l}\text { Overhead } \\
\text { costs of } \\
\text { each } \\
\text { product } \\
\text { per ton } \\
\text { (dollars) }\end{array}$ & $\begin{array}{l}\text { Overhead } \\
\text { costs of } \\
\text { each } \\
\text { product } \\
\text { (dollars)/ } \\
\text { sales } \\
\text { (tons) }\end{array}$ & 0.51 & 0.31 & 0.83 & 0.60 & & \\
\hline
\end{tabular}

Then, based on similar calculations in all factories, the average production price (with and without overhead costs), sales price, and sales profit per ton of each product are calculated (Table 5 for 2016). 
Table 5

Average production price, sales price and sales profit per ton of steel products in 2016

\begin{tabular}{|c|c|c|c|c|c|c|c|c|}
\hline & Calculation formula & Concentrate & Granules & Pellet & Apatite & $\begin{array}{l}\text { Sponge } \\
\text { Iron }\end{array}$ & $\begin{array}{l}\text { Steel } \\
\text { ignots }\end{array}$ & $\begin{array}{l}\text { Steel } \\
\text { products }\end{array}$ \\
\hline $\begin{array}{l}\text { Average } \\
\text { production } \\
\text { price of } \\
\text { product } \\
\text { (without } \\
\text { overhead } \\
\text { costs) per ton } \\
\text { (dollars) }\end{array}$ & $\begin{array}{l}\text { final cost of each } \\
\text { product in different } \\
\text { factories (dollars)/ } \\
\text { total sales of each } \\
\text { product in different } \\
\text { factories (tons) }\end{array}$ & 31.11 & 18.89 & 47.91 & 36.40 & 140.80 & 276.40 & 343.09 \\
\hline $\begin{array}{l}\text { Average } \\
\text { overhead costs } \\
\text { of production } \\
\text { of product per } \\
\text { ton (dollars) }\end{array}$ & $\begin{array}{l}\text { total overhead costs of } \\
\text { each product in } \\
\text { different factories } \\
\text { (dollars)/ total sales of } \\
\text { each product in } \\
\text { different factories } \\
\text { (tons) }\end{array}$ & 2.94 & 0.60 & 6.06 & 0.60 & 6.89 & 29.37 & 18.80 \\
\hline $\begin{array}{l}\text { Average } \\
\text { production } \\
\text { price of } \\
\text { product (with } \\
\text { overhead } \\
\text { costs) per ton } \\
\text { (dollars) }\end{array}$ & $\begin{array}{l}\text { Total average } \\
\text { production price of } \\
\text { product (without } \\
\text { overhead costs) per ton } \\
\text { (dollars) + average } \\
\text { overhead cost of } \\
\text { production of product } \\
\text { per ton (dollars) }\end{array}$ & 34.06 & 19.49 & 53.97 & 37.00 & 147.69 & 305.77 & 361.89 \\
\hline $\begin{array}{l}\text { Average sale } \\
\text { price of } \\
\text { product per ton } \\
\text { (dollars) }\end{array}$ & $\begin{array}{l}\text { Total sales of each } \\
\text { product in different } \\
\text { factories (dollars)/ } \\
\text { total sales of each } \\
\text { product in different } \\
\text { factories (tons) }\end{array}$ & 49.63 & 28.94 & 77.86 & 55.29 & 173.86 & 363.26 & 402.17 \\
\hline $\begin{array}{l}\text { Average profit } \\
\text { from the sale } \\
\text { of each ton of } \\
\text { product } \\
\text { (dollars) }\end{array}$ & $\begin{array}{l}\text { Average sale price of } \\
\text { product per ton } \\
\text { (dollars) - average } \\
\text { production price of } \\
\text { product per ton } \\
\text { (dollars) }\end{array}$ & 15.54 & 9.46 & 23.89 & 18.29 & 26.17 & 57.49 & 40.29 \\
\hline
\end{tabular}


Table 6

Value and added value of production of the production of one ton of each steel product in 2016 (thousand dollars)

\begin{tabular}{|c|c|c|c|c|c|}
\hline & Value & $\begin{array}{l}\text { Added } \\
\text { value }\end{array}$ & $\begin{array}{l}\text { Share of added } \\
\text { value from final } \\
\text { price }\end{array}$ & $\begin{array}{l}\text { Share of added } \\
\text { value from total } \\
\text { costs }\end{array}$ & $\begin{array}{l}\text { Cumulative share of added } \\
\text { value from total costs }\end{array}$ \\
\hline $\begin{array}{l}\text { Concentrate without } \\
\text { overhead }\end{array}$ & 31.14 & 31.14 & 8.57 & - & 8.57 \\
\hline $\begin{array}{l}\text { Overhead of } \\
\text { concentration }\end{array}$ & 34.00 & 2.86 & 0.81 & - & 9.38 \\
\hline Pellet without overhead & 48.00 & 14.00 & 3.81 & - & 13.19 \\
\hline $\begin{array}{l}\text { Overhead of pellet } \\
\text { production }\end{array}$ & 54.00 & 6.00 & 1.67 & - & 14.86 \\
\hline $\begin{array}{l}\text { Added value of } \\
\text { processing units }\end{array}$ & 78.00 & 24.00 & 6.58 & 22.22 & 21.43 \\
\hline $\begin{array}{l}\text { Sponge iron without } \\
\text { overhead }\end{array}$ & 140.86 & 62.86 & 17.32 & - & 38.76 \\
\hline $\begin{array}{l}\text { Overhead of the } \\
\text { production of sponge } \\
\text { iron }\end{array}$ & 147.71 & 6.86 & 1.90 & - & 40.65 \\
\hline $\begin{array}{l}\text { Added value of } \\
\text { reduction units }\end{array}$ & 173.71 & 26.00 & 7.21 & 24.34 & 47.86 \\
\hline $\begin{array}{l}\text { Crude steel without } \\
\text { overhead }\end{array}$ & 276.29 & 102.57 & 28.23 & - & 76.09 \\
\hline $\begin{array}{l}\text { Overhead of the } \\
\text { production of crude } \\
\text { steel }\end{array}$ & 305.71 & 29.43 & 8.08 & - & 84.18 \\
\hline $\begin{array}{l}\text { Added value of smelting } \\
\text { units }\end{array}$ & 363.14 & 57.43 & 15.82 & 53.44 & 100.00 \\
\hline Total value & 363.14 & 363.14 & 100.00 & - & 100.00 \\
\hline Total profit & 107.43 & - & 29.61 & - & 29.61 \\
\hline Total overhead & 45.14 & - & 12.46 & - & 12.46 \\
\hline
\end{tabular}

Accordingly, the added value in the Iranian steel industry chain in 2016 is presented in Figure 4.

Also, the performance of each sector of the value chain is compared in Fig. 5.

[2] http://chadormalu.com/en-us/AboutCompany

\section{Conclusions}

In this article, the value of Iran's steel industry is examined from the perspective of economic and material flow analysis to provide a holistic and accurate view of the steel industry and its dynamic components. Accordingly, the policymakers can design appropriate policies and interventions to improve the chain by the recognition of production bottlenecks and consequently, the roots of chain inefficiency. In this regard, the inaccuracy of information in the material flow analysis is partially solved by the concurrent usage of value chain analysis as the data is collected by different organizations for diverse purposes. Thus the simultaneous use of the aforementioned information validates the research results; although the researchers have also attempted to use more than one source for the required data as well. According to the findings of the research, the following results is inferred: 
1) The production costs of the intermediate products before steel are all cheaper than their imported prices, and in this regard, Iran has a competitive advantage of cheaper raw materials in the upper chains of the value chain. According to the significant share of shipping in final costs of the industry, the advantage is due to the easy access to the products. Despite Iran's advantage in the early stages of the chain, the final price of domestic production of steel is higher than the price of the imported steel, which indicates an increase in the share of overhead costs due to the production in low-capacity. Surprisingly, the difference between nominal capacity and actual production in different links in the chain is not much dependent on market demand or the excess/lack of capacity of the link. For example, although there was a lack of pellet production capacity in the last three years, the actual production of the pelletizing plants was less than their nominal capacity.

2) Weakness in transportation as one of the reasons for deviating from the nominal capacity, especially in the upstream echelons of the industry is due to the ignorance of the geographical proximity of iron ore processing plants to consumer plants on one hand, and the high volume of company-to-company exchanges in upstream industries which is Noncompliance with the transportation capacity. Accordingly, as an example, part of the country's iron ore processing capacity in the Sangan region has remained unused as a result of the difficulty in the transportation of its products.

3) The difference between nominal capacity and actual production in different echelons does not have a specific dependence on the added value of production in that echelon. For example, between 2014 and 2015, although the difference in added value in the smelting sector was very high, the productivity of the smelters was not much different. Also in 2016, the added value in the smelting sector has almost quadrupled compared to 2015 , but the actual production of crude steel in these two years was 11 and 7 million tons less than its nominal capacity, respectively.

4) Despite the reduction of production costs in 2015 compared to 2014, the profit of the steel industry decreased in 2015. Also, the smelting sector went through a difficult fiscal year with a sharp decline in profitability and probably relied on government support to cover its costs.

5) Although the share of profits of the upstream links in the value chain has not fluctuated much over time, the share of downstream profits is dependent on the final price. Indeed, the fluctuations in final price may lead to a lack of advantage in downstream industries, but upstream industries have a permanent advantage. Therefore, easy access to the minerals, lower transportation costs, and national advantages in energy costs provide a competitive advantage in the upstream industries.

6) Due to the bottleneck of the pelletizing and the lack of capacity for the exploitation of surplus iron ore and production concentrate, miners and iron ore processing plants are forced to export iron ore and concentrate with the lowest added value. In other words, the low productivity and the gap between actual production and nominal capacity in pellet production have led to the reduction of the generated added value of 12, 30, and 240 million dollars in 2014-2016, respectively.

7) The profit margin of iron ore processing companies is significantly higher comparing to the reduction and smelting sectors due to the export of granulated iron ore and low required investments. As a result, Iran has invested deeply in the sector without moving towards further exploitation of these mineral assets.

8) Given the vacant capacity in different links of the chain, there is a great opportunity for wage conversion or commodity purification contracts to reduce the share of overhead costs in production. Accordingly, the sponge iron factories for example could increase their average added up to $8 \%$ in 2016.

9) Pricing of intermediate products based on a ratio of steel ingot prices seems to be a failed policy as the added value is not evenly distributed throughout the chain. For example, although the total profit of the iron ore processing plants has been relatively constant in the last three years, the profit in the smelting and reduction sectors has varied according to the final price of steel.

10) Iran's steel industry has suffered from severe value chain imbalances in the past few years. Due to the difference in actual production and nominal capacity in each part of the value chain, the amount of need or surplus in each link of the chain is different from what is determined based on the nominal capacity, and this difference has led to frequent imports and exports 
throughout the value chain. For example, Iran has imported more than 1 million tons of pellets and exported more than 13 million tons of iron ore and iron concentrate in 2015.

As mentioned earlier, the study of Iran's steel industry in 2017 - 2020 requires attention to the intensification of international sanctions on Iran. Therefore, for future research, it is suggested to analyze the value chain of Iran's steel industry in this period with a similar approach, and then compare the results with this research to evaluate the impact of the sanctions on this industry. Also, the findings of the present study can be further investigated by the analysis of the effects of the identified challenges in the value chain of Iran's steel industry (such as the inappropriate geographical dispersion of the chain components, the deviation from nominal production capacity, and the imbalance in the development of industry value chain). Finally, considering the use of alternative technologies in the steel industry of most countries, the scholars can analyze the steel value chain in other contexts and then compare the added value of different steel production technologies.

\section{Declarations}

\section{Funding}

This research received no specific grant from any funding agency in the public, commercial, or not-for-profit sectors.

\section{Competing Interests}

The authors have no relevant financial or non-financial interests to disclose.

\section{Author Contributions}

Sepehr Ghazinoory managed the research project, Abolfazl Adab provided the core content of the research (literature review, data, and findings), and Mehdi Fatemi developed the research paper.

\section{Data Availability}

The datasets generated during and/or analysed during the current study are available from the corresponding author on reasonable request.

\section{References}

1. Adab, A., Ghazinoory, S., Ghazinoori, S., Shahverdi, H., (2018). The strategies of Iran steel industry value chain upgrading through innovation system perspective [In Persian]. Journal of Science and Technology Policy, 11(4), 2-16.

2. Analoui, F., Labbaf, H., Noorbakhsh, F., (2000). Identification of clusters of managerial skills for increased effectiveness: The case of the steel industry in Iran. International Journal of Training and Development, 4(3), pp.217-234.

3. Andersen, J.P., and Hyman, B., (2001). Energy and material flow models for the US steel industry. Energy, 26(2), pp.137-159.

4. Ansari, N., Seifi, A., (2012). A system dynamics analysis of energy consumption and corrective policies in Iranian iron and steel industry. Energy, 43(1), pp.334-343.

5. Arabzad, S.M., Ghorbani, M. and Ranjbar, M.J., (2017). Fuzzy Goal Programming for Linear Facility Location-Allocation in a Supply Chain; The Case of Steel Industry. International Journal of Research in Industrial Engineering, 6(2), pp.90-105.

6. Azadeh, A., Neshat, N., Mardan, E., Saberi, M., (2013). Optimization of steel demand forecasting with complex and uncertain economic inputs by an integrated neural network-fuzzy mathematical programming approach. The International Journal of Advanced Manufacturing Technology, 65(5-8), pp.833-841.

7. Brunner P.H., Rechberger, H., (2004). Practical handbook of material flow analysis, Lewis publishers.

8. Dahlström, K., Ekins, P., (2006). Combining economic and environmental dimensions: Value chain analysis of UK iron and steel flows. Ecological Economics, 58(3), pp.507-519. 
9. Dahlström, K., \& Ekins, P., (2007). Combining economic and environmental dimensions: Value chain analysis of UK aluminium flows. Resources, conservation and recycling, 51(3), 541-560.

10. Dahlström, K., Ekins, P., He, J., Davis, J., Clift, R., (2004). Iron, steel and aluminium in the UK: material flows and their economic dimensions. London: Policy Studies Institute.

11. Dekker, H.C., (2003). Value chain analysis in interfirm relationships: A field study. Management accounting research, 14(1), pp.1-23.

12. Donaldson, K.M., Ishii, K., Sheppard, S.D., (2004, January). Customer value chain analysis. In International Design Engineering Technical Conferences and Computers and Information in Engineering Conference (Vol. 46962, pp. 993-1001).

13. Dudin, M.N., (2017). Green technology and renewable energy in the system of the steel industry in Europe.

14. Ecorys SCS Group, (2008). Study on the Competitiveness of the European Steel Sector. Within the Framework Contract of Sectoral Competitiveness Studies-ENTR/06/054. Directorate-General Enterprise \& Industry. Rotterdam.

15. Faße, A., Grote, U., Winter, E., (2009). Value chain analysis methodologies in the context of environment and trade research (No. 429). Diskussionsbeitrag.

16. Fearne, A., Martinez, M.G., Dent, B., (2012. Dimensions of sustainable value chains: implications for value chain analysis. Supply Chain Management: An International Journal.

17. Fischer-Kowalski, M., Hüttler, W., 1998). Society's Metabolism: The Intellectual History of Materials Flow Analysis, Part II, 1970-1 998. Journal of industrial ecology, 2(4), pp.107-136.

18. Gauffin, A., Andersson, N.Å., Storm, P., Tilliander, A., Jönsson, P.G., (2016). The global societal steel scrap reserves and amounts of losses. Resources, 5(3), p.27.

19. GTZ Eschborn, (2007, The Methodology of Value Chain Promotion, ValueLinks Module 01.

20. Hansen, M.T., Birkinshaw, J., (2007). The innovation value chain. Harvard business review, 85(6), p.121.

21. Hartwich, F., Kormawa, P., (2009). Value Chain Diagnostics for Industrial Development. Building blocks for a holistic and rapid analytical tool. Vienna: United Nations Industrial Development Organization (UNIDO).

22. Hasanbeigi, A., Price, L., Chunxia, Z., Aden, N., Xiuping, L., Fangqin, S., (2014). Comparison of iron and steel production energy use and energy intensity in China and the US. Journal of Cleaner Production, 65, pp.108-119.

23. Hastorun, S., Renaud, K.M., Lederer, G.W., (2016). Recent trends in the nonfuel minerals industry of Iran (No. 1421). US Geological Survey.

24. He, K., Wang, L., Zhu, H., Ding, Y., (2018). Energy-saving potential of China's steel industry according to its development plan. Energies, 11(4), p.948.

25. Hefley, B., Seydor, S., (2011). The economic impact of the value chain of a Marcellus shale well. Available at SSRN 2181675.

26. Hellin, J., Meijer, M., (2006). Guidelines for value chain analysis. Food and Agriculture Organization of the United Nations (FAO), Rome, Italy.

27. Johansson, M.T., Söderström, M., (2011). Options for the Swedish steel industry-Energy effıciency measures and fuel conversion. Energy, 36(1), pp.191-198.

28. Jozi, S.A., Majd, N.M., (2014). Health, safety, and environmental risk assessment of steel production complex in central Iran using TOPSIS. Environmental monitoring and assessment, 186(10), pp.6969-6983.

29. Kaplinsky, R., Morris, M., (2000). A handbook for value chain research (Vol. 113). Brighton: University of Sussex, Institute of Development Studies.

30. Kaplinsky, R., (2000). Spreading the gains from globalisation: What can be learned from chain analysis. Brighton, England: Institute of Development Studies, University of Sussex.

31. Kordzadeh, E., Mourão, J.M., Schwalm, T., (2018). AN outlook to Iranian iron ore and ironmaking industries. $48^{\circ}$ Seminário de Redução de Minério de Ferro e Matérias-Primas e $6^{\circ}$ Simpósio Brasileiro de Aglomeração de Minério de Ferro, part of the ABM Week, October 2nd-4th, (2018, São Paulo, SP, Brazil. 
32. Kumar, N., Chadha, A., (2009). India's outward foreign direct investments in steel industry in a Chinese comparative perspective. Industrial and corporate change, 18(2), pp.249-267.

33. Lee, C.C., Yang, J., (2000). Knowledge value chain. Journal of management development.

34. Lee, K., Ki, J.H., (2017). Rise of latecomers and catch-up cycles in the world steel industry. Research Policy, 46(2), pp.365375.

35. Mabashi, D., (2018). Recent developments in steelmaking capacity. OECD.

36. Mahjouri, M., Ishak, M.B., Torabian, A., Abd Manaf, L., Halimoon, N., (2017). Determining the best practicable control technology and its associated emission levels for Iron and steel industry in Iran. Resources, Conservation and Recycling, 127, pp.114-123.

37. McKinsey, (2013). Competitiveness and challenges in the steel industry, ECD Steel committee.

38. Mehmanpazir, F., Khalili-Damghani, K., Hafezalkotob, A., (2019. Modeling steel supply and demand functions using logarithmic multiple regression analysis (case study: Steel industry in Iran). Resources Policy, 63, p.101409.

39. Michaelis, P., Jackson, T., (2000a). Material and energy flow through the UK iron and steel sector. Part 1: 1954-1994. Resources, Conservation and Recycling, 29(1-2), pp.131-156.

40. Michaelis, P., Jackson, T., (2000b). Material and energy flow through the UK iron and steel sector: Part 2: 1994-2019. Resources, Conservation and Recycling, 29(3), pp.209-230.

41. Nabatian, G., Rastad, E., Neubauer, F., Honarmand, M., Ghaderi, M., (2015). Iron and Fe-Mn mineralisation in Iran: implications for Tethyan metallogeny. Australian Journal of Earth Sciences, 62(2), pp.211-241.

42. Nezhad, M.Z., Anvari, E., (2008). Prediction of Iron and Steel Consumption of Iran Using Panel Data. Journal of Applied Sciences, 8(2), pp.364-368.

43. Ning, G., Zhen, Z., Wang, P., Li, Y., Yin, H., (2012). Economic analysis on value chain of taxi fleet with battery-swapping mode using multiobjective genetic algorithm. Mathematical Problems in Engineering, 2012.

44. Pal, P., Gupta, H., Kapur, D., (2016). Carbon mitigation potential of Indian steel industry. Mitigation and adaptation strategies for global change, 21(3), pp.391-402.

45. Panasiyk, D., Laratte, B., Remy, S., (2016). Steel stock analysis in Europe from 1945 to 2013. Procedia Cirp, 48, pp.348-351.

46. Pil, F.K., Holweg, M., (2006). Evolving from value chain to value grid. MIT Sloan Management Review, 47(4), p.72.

47. Purcell, S.W., Crona, B.I., Lalavanua, W., Eriksson, H., (2017). Distribution of economic returns in small-scale fisheries for international markets: a value-chain analysis. Marine Policy, 86, pp.9-16.

48. Reichl, C., Schatz, M., \& Zsak, G., (2016). World mining data: Vienna, Austria, International Organizing Committee for the World Mining Congress, v. 31, 248 p., accessed June 15, (2016.

49. Rahdari, H., Forouzan, A., Ramezankhani, A., Foroughi, P., (2007). Analyzing the Effect of Global Steel Price Fluctuation on Iran's Steel-Maker Stock Prices: A System Dynamics Approach. World, pp.1-344.

50. Roper, S., Du, J., Love, J.H., (2008). Modelling the innovation value chain. Research policy, 37(6-7), pp.961-977.

51. Savino, M.M., Manzini, R., Mazza, A., (2015). Environmental and economic assessment of fresh fruit supply chain through value chain analysis. A case study in chestnuts industry. Production Planning \& Control, 26(1), pp.1-18.

52. Shahabi, R.S., Basiri, M.H., Kahag, M.R., Zonouzi, S.A., (2014). An ANP-SWOT approach for interdependency analysis and prioritizing the Iran $\square \mathrm{s}$ steel scrap industry strategies. Resources policy, 42, pp.18-26.

53. Shakouri, B., (2017). Opportunities for Foreign Direct investment in Iran Iron ore \& Steel Industries. 5th World DRI \& Pellet Congress. Park Hyatt Dubai, United Arab Emirates.

54. Shekari, H., Shirazi, S., Afshari, M., Veyseh, S., (2011). Analyzing the key factors affecting the green supply chain management: A case study of steel industry. Management Science Letters, 1(4), pp.541-550.

55. Shinoj, P., Raju, S.S., Kumar, P., Msangi, S., Yadav, P., Thorat, V.S., Chaudhary, K.R., (2010). An economic assessment along the Jatropha-based biodiesel value chain in India. Agricultural Economics Research Review, 23(347-(2016-16937), pp.393404. 
56. Siitonen, S., Tuomaala, M., Ahtila, P., (2010). Variables affecting energy efficiency and CO2 emissions in the steel industry. Energy Policy, 38(5), pp.2477-2485.

57. Springer-Heinze, A. (2007). ValueLinks Manual: The methodology of value chain promotion.

58. Subramanian, U., (2007). Moving toward competitiveness: A value chain approach.

59. World Steel Association, (2019). World Steel in Figures 2019.

60. Xiong, G., Helo, P., (2008). Challenges to the supply chain in the steel industry. International Journal of Logistics Economics and Globalisation, 1(2), pp.160-175.

61. Yellishetty, M., Ranjith, P.G., Tharumarajah, A., (2010). Iron ore and steel production trends and material flows in the world: Is this really sustainable?. Resources, conservation and recycling, 54(12), pp.1084-1094.

\section{Figures}

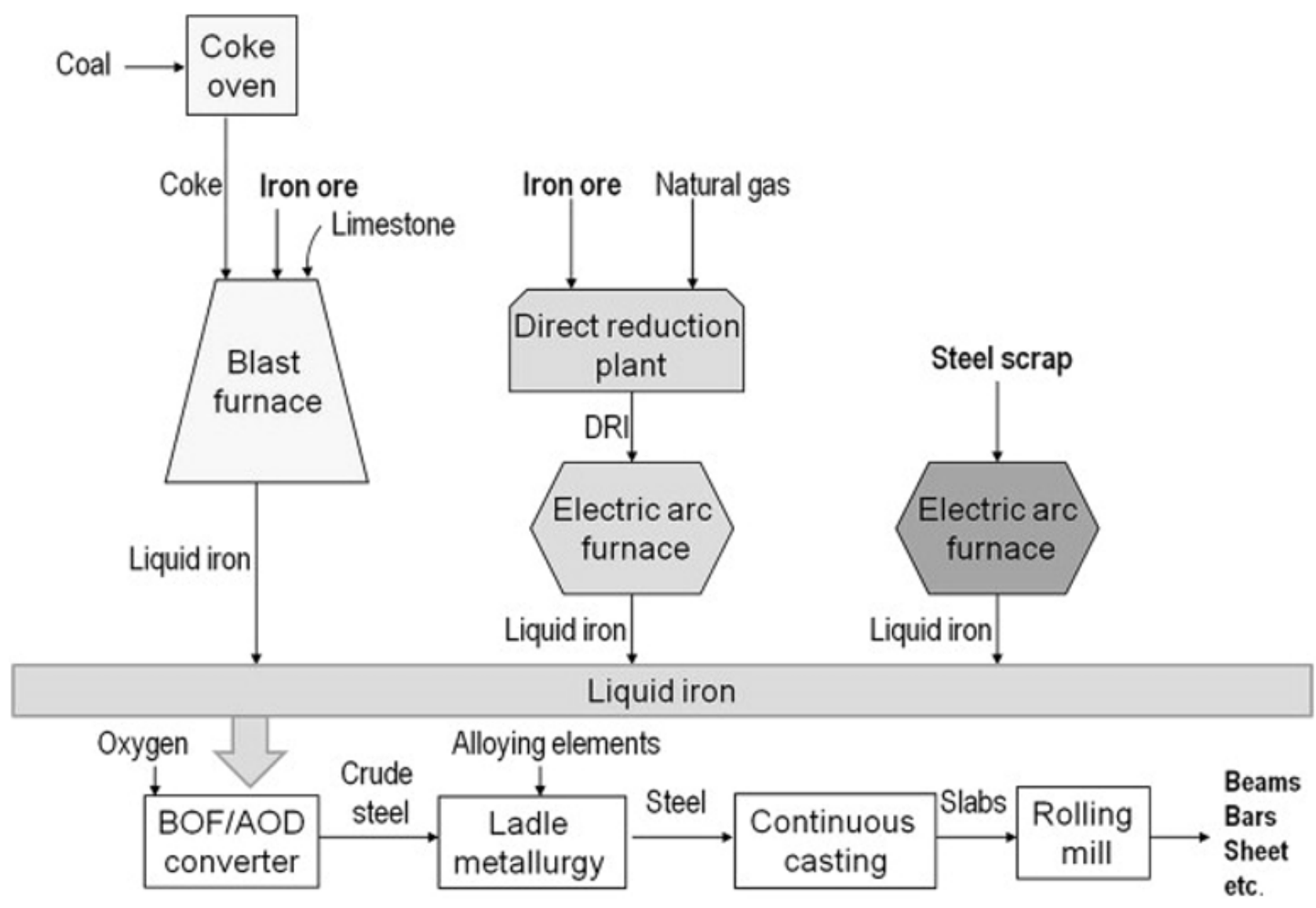

Figure 1

Main methods of steel production (Johansson \& Soderstrum, 2011) 


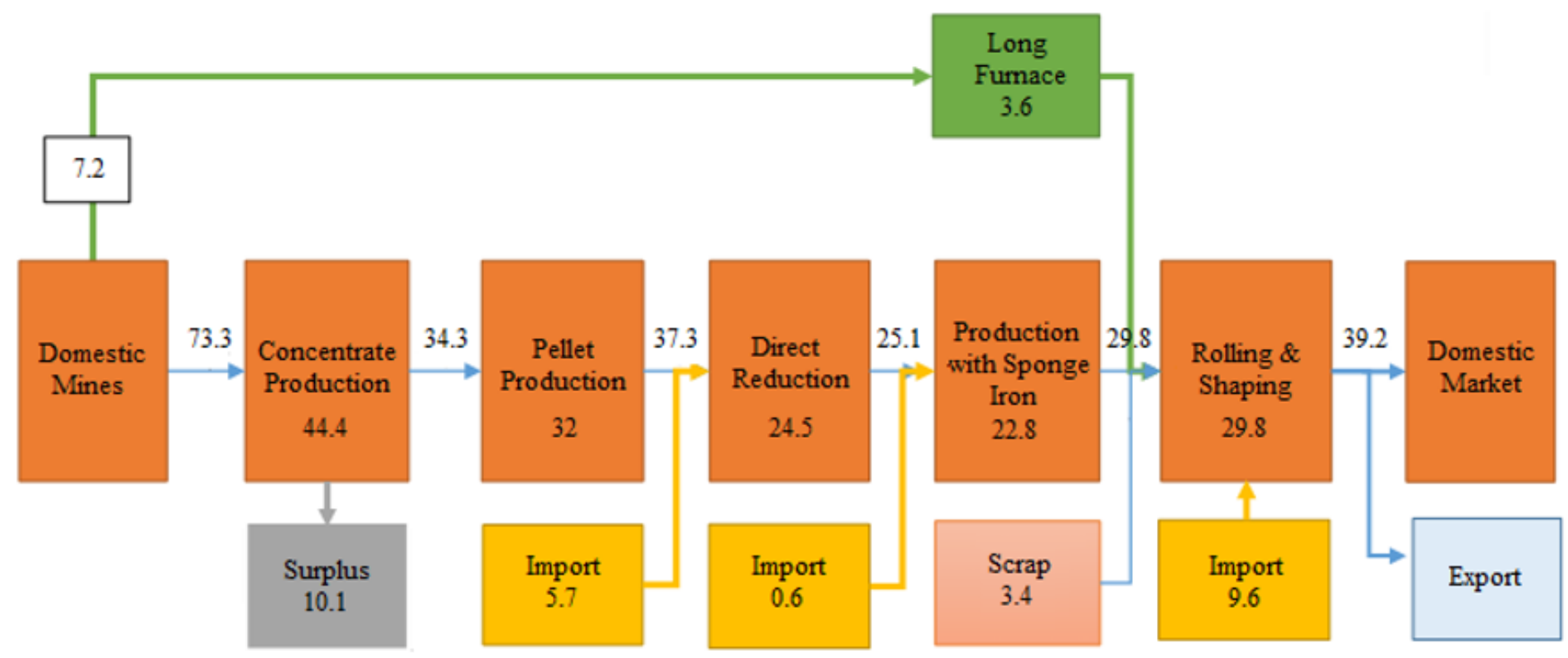

Figure 2

Material flow analysis of Iranian steel industry in 2016 based on production in the last echelon of the chain (million tons)

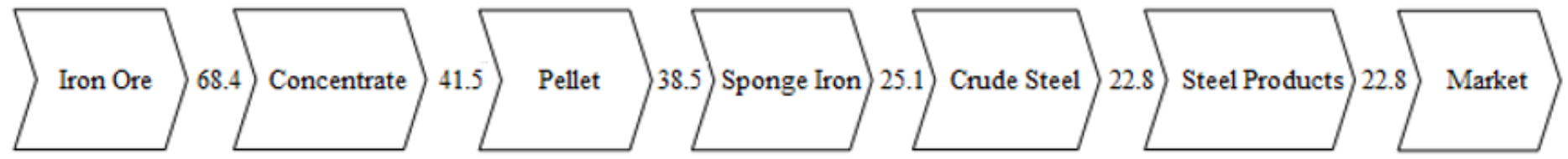

Figure 3

Actual material flow of Iranian steel industry in 2016 based on the maximum production capacity of the bottleneck echelon (million tons) 


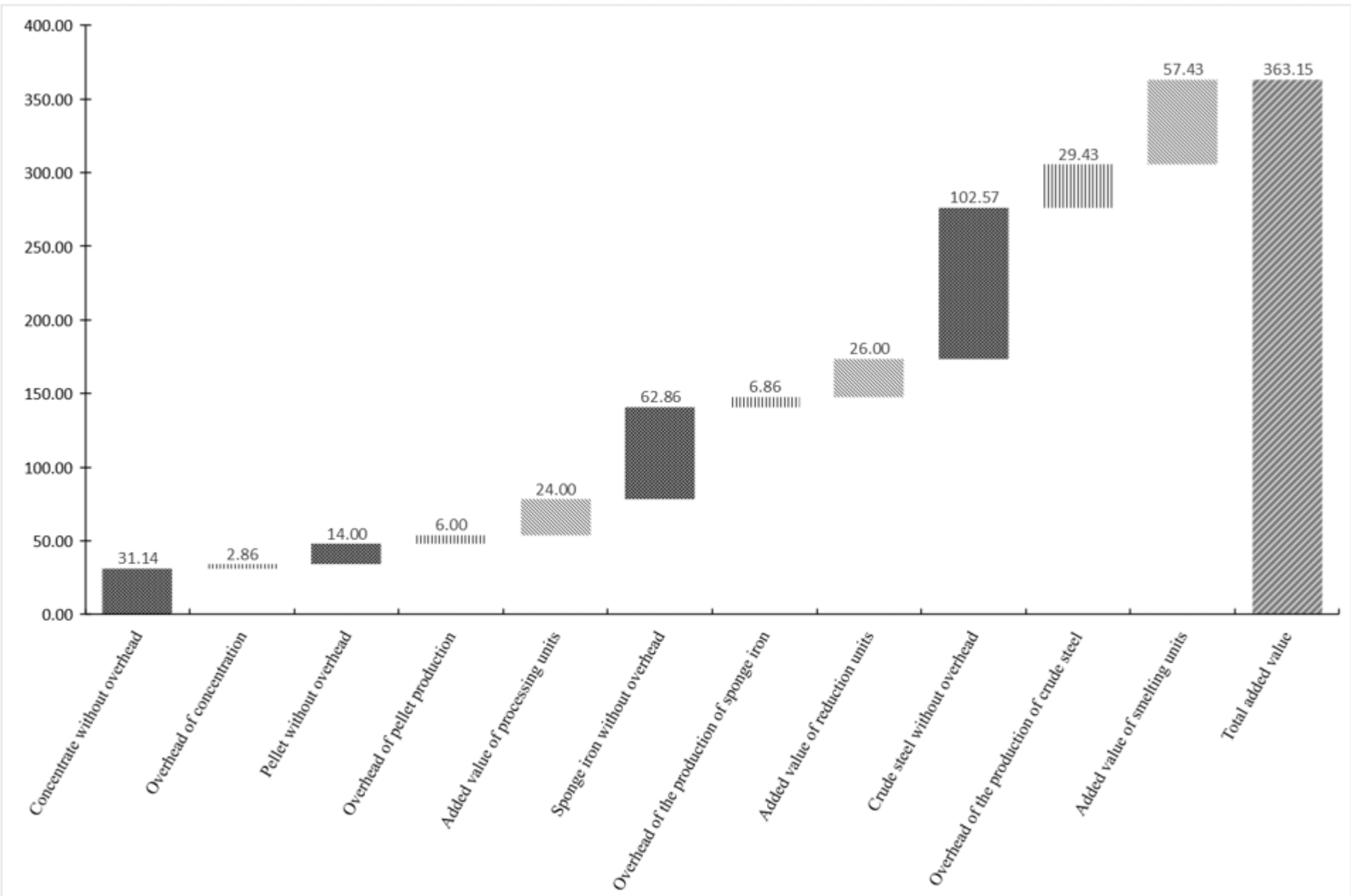

Figure 4

Added value of the production of one ton of each steel products in 2016 (thousand dollars)

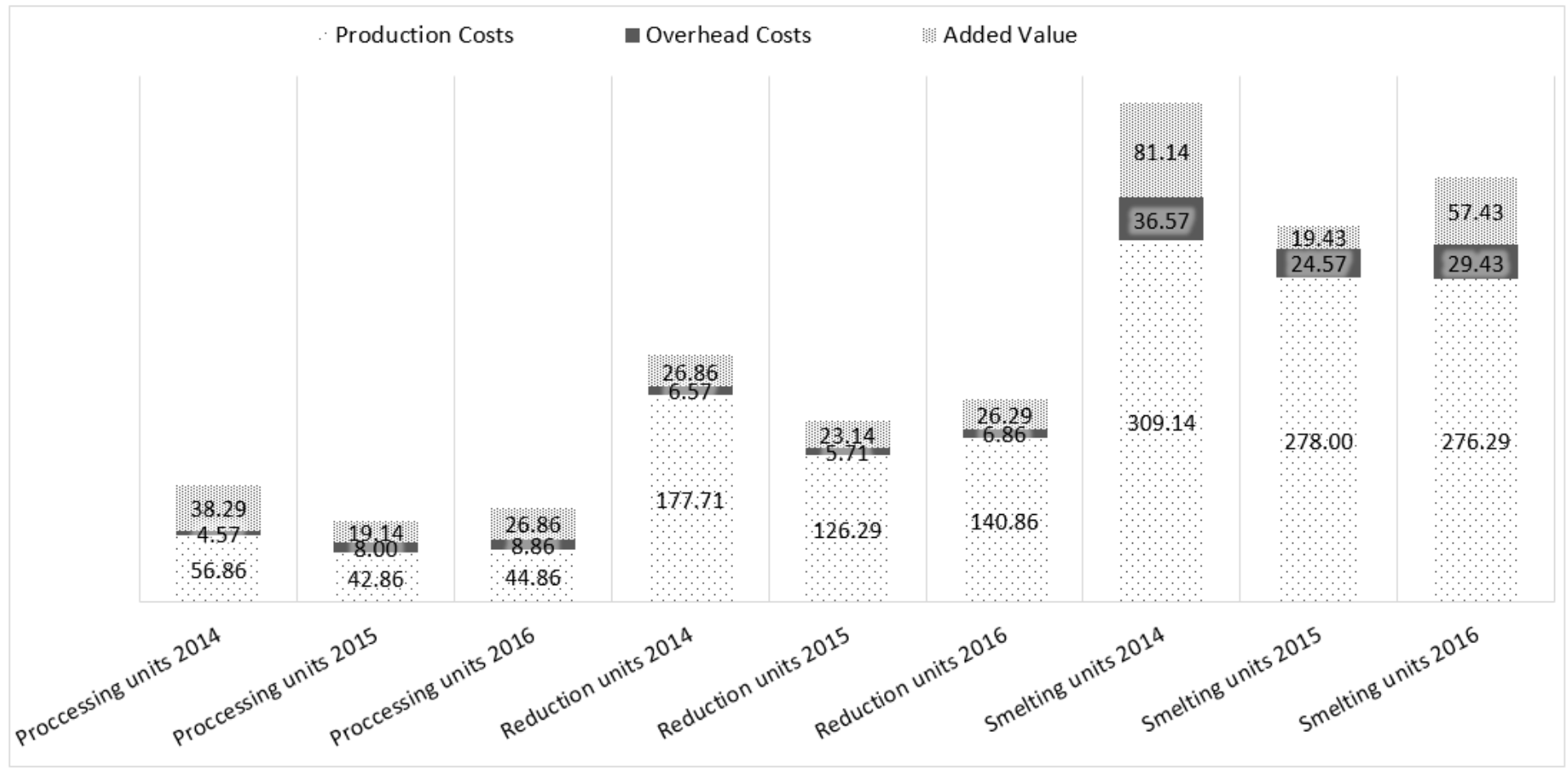

Figure 5 
Comparison of production costs, overhead costs and added value of the production of one ton of each product in different units of the Iranian steel industry (2014 - 2016) (thousand dollars)

\section{Supplementary Files}

This is a list of supplementary files associated with this preprint. Click to download.

- IranSteelValueChainGraphicalAbstract.png 